\title{
Front Matter: Volume 9372
}

, "Front Matter: Volume 9372," Proc. SPIE 9372, High Contrast Metastructures IV, 937201 (26 March 2015); doi: 10.1117/12.2190557

SPIE. Event: SPIE OPTO, 2015, San Francisco, California, United States 


\title{
PROCEEDINGS OF SPIE
}

\section{High Contrast Metastructures IV}

\author{
Connie J. Chang-Hasnain \\ David Fattal \\ Fumio Koyama \\ Weimin Zhou \\ Editors
}

\author{
11-12 February 2015 \\ San Francisco, California, United States
}

Sponsored and Published by

SPIE 
The papers included in this volume were part of the technical conference cited on the cover and title page. Papers were selected and subject to review by the editors and conference program committee. Some conference presentations may not be available for publication. The papers published in these proceedings reflect the work and thoughts of the authors and are published herein as submitted. The publisher is not responsible for the validity of the information or for any outcomes resulting from reliance thereon.

Please use the following format to cite material from this book:

Author(s), "Title of Paper," in High Contrast Metastructures IV, edited by Connie J. Chang-Hasnain, David Fattal, Fumio Koyama, Weimin Zhou, Proceedings of SPIE Vol. 9372 (SPIE, Bellingham, WA, 2015) Article CID Number.

ISSN: 0277-786X

ISBN: 9781628414622

Published by

SPIE

P.O. Box 10, Bellingham, Washington 98227-0010 USA

Telephone +1 3606763290 (Pacific Time) · Fax +1 3606471445

SPIE.org

Copyright (c) 2015, Society of Photo-Optical Instrumentation Engineers.

Copying of material in this book for internal or personal use, or for the internal or personal use of specific clients, beyond the fair use provisions granted by the U.S. Copyright Law is authorized by SPIE subject to payment of copying fees. The Transactional Reporting Service base fee for this volume is $\$ 18.00$ per article (or portion thereof), which should be paid directly to the Copyright Clearance Center (CCC), 222 Rosewood Drive, Danvers, MA 01923. Payment may also be made electronically through CCC Online at copyright.com. Other copying for republication, resale, advertising or promotion, or any form of systematic or multiple reproduction of any material in this book is prohibited except with permission in writing from the publisher. The CCC fee code is 0277-786X/15/\$18.00.

Printed in the United States of America.

Publication of record for individual papers is online in the SPIE Digital Library.

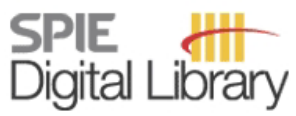

SPIEDigitalLibrary.org

Paper Numbering: Proceedings of SPIE follow an e-First publication model, with papers published first online and then in print. Papers are published as they are submitted and meet publication criteria. A unique citation identifier (CID) number is assigned to each article at the time of the first publication. Utilization of CIDs allows articles to be fully citable as soon as they are published online, and connects the same identifier to all online, print, and electronic versions of the publication. SPIE uses a six-digit CID article numbering system in which:

- The first four digits correspond to the SPIE volume number.

- The last two digits indicate publication order within the volume using a Base 36 numbering

system employing both numerals and letters. These two-number sets start with 00, 01, 02, 03, 04,

05, 06, 07, 08, 09, 0A, OB ... 0Z, followed by 10-1Z, 20-2Z, etc.

The CID Number appears on each page of the manuscript. The complete citation is used on the first page, and an abbreviated version on subsequent pages. 


\title{
Contents
}

\author{
$\checkmark$ Authors \\ vii Conference Committee
}

\section{SESSION 1 HARNESSING LIGHT}

937203 High index contrast integrated optics in the cylindrical coordinate (Invited Paper) [9372-2]

\section{SESSION 2 VCSELS}

937206 High-contrast grating reflectors for $980 \mathbf{n m}$ vertical-cavity surface-emitting lasers (Invited Paper) [9372-5]

937207 Fabrication of SiC membrane HCG blue reflector using nanoimprint lithography [9372-6]

937208 Heterogeneously-integrated VCSEL using high-contrast grating on silicon [9372-7]

\section{SESSION 3 RESONATORS}

937209 Membrane-in-the-middle optomechanics with high-contrast gratings (Invited Paper) [9372-8]

9372 0C Light emission characteristics of nonpolar a-plane GaN-based photonic crystal defect cavities (Invited Paper) [9372-11]

9372 OD Air-suspended $\mathrm{TiO}_{2}$-based $\mathrm{HCG}$ reflectors for visible spectral range [9372-12]

\section{SESSION 4 NOVEL DEVICES}

9372 OE Virtually image phased array based on Bragg reflector waveguide for large-port optical switching (Invited Paper) [9372-13]

9372 OF Bringing mirrors to rest: grating concepts for ultra-precise interferometry (Invited Paper) [9372-14]

9372 OG Low-loss adiabatically-tapered high-contrast gratings for slow-wave modulators on SOI [9372-15]

$9372 \mathrm{OH}$ Highly efficient polarization control using subwavelength high contrast transmitarrays [9372-16] 
9372 0J Design and fabrication of 3D high-contrast metastructure THz cage waveguides [9372-18]

9372 OK Active coloration with flexible high contrast metastructures [9372-19]

\section{SESSION 6 ENGINEERING OF METASTRUCTURES}

9372 ON Parameter-tolerant design of high contrast gratings (Invited Paper) [9372-22]

937200 On-chip broadband spectral filtering using planar double high-contrast grating reflectors [9372-23]

9372 OP Efficient high NA flat micro-lenses realized using high contrast transmitarrays [9372-24]

\section{SESSION 7 REFLECTORS AND RESONATORS}

9372 OS GaAs/AIOx high-contrast grating mirrors for mid-infrared VCSELs (Invited Paper) [9372-27]

9372 OT Antireflection subwavelength gratings on optical fiber tips fabricated by a dedicated UV nano imprint lithography system (Invited Paper) [9372-28]

9372 OU Integration of GaAs-based VCSEL array on SiN platform with HCG reflectors for WDM applications [9372-29]

9372 OV Perturbation model for the control of the spectral properties of high contrast gratings [9372-30]

9372 OW Guided resonance reflective phase shifters [9372-31] 


\title{
Conference Committee
}

\author{
Symposium Chairs
}

David L. Andrews, University of East Anglia

(United Kingdom)

Alexei L. Glebov, OptiGrate Corporation (United States)

Symposium Co-chairs

Jean-Emmanuel Broquin, IMEP-LAHC (France)

Shibin Jiang, AdValue Photonics, Inc. (United States)

Program Track Chair

Ali Adibi, Georgia Institute of Technology (United States)

\section{Conference Chairs}

Connie J. Chang-Hasnain, University of California, Berkeley (United States)

David Fattal, LEIA Inc. (United States)

Fumio Koyama, Tokyo Institute of Technology (Japan)

Weimin Zhou, U.S. Army Research Laboratory (United States)

Conference Program Committee

Markus-Christian Amann, Walter Schottky Institut (Germany)

II-Sug Chung, Technical University of Denmark (Denmark)

Ernst-Bernhard Kley, Friedrich-Schiller-Universität Jena (Germany)

Philippe Lalanne, Institut d'Optique Graduate School (France)

John R. Lawall, National Institute of Standards and Technology

(United States)

Tien-Chang Lu, National Chiao Tung University (Taiwan)

Rainer F. Mahrt, IBM Research - Zürich (Switzerland)

Gunther Roelkens, Universiteit Gent (Belgium)

Pierre Viktorovitch, Ecole Centrale de Lyon (France)

Alan E. Willner, The University of Southern California (United States)

Ming C. Wu, University of California, Berkeley (United States)

Anshi Xu, Peking University (China) 
Session Chairs

1 Harnessing Light

Fumio Koyama, Tokyo Institute of Technology (Japan)

2 VCSELS

Connie J. Chang-Hasnain, University of California, Berkeley (United States)

3 Resonators

Siyuan Yu, University of Bristol (United Kingdom)

4 Novel Devices

Tien-Chang Lu, National Chiao Tung University (Taiwan)

5 Metastructures

John R. Lawall, National Institute of Standards and Technology (United States)

6 Engineering of Metastructures

Andrea Fiore, Technische Universiteit Eindhoven (Netherlands)

7 Reflectors and Resonators

Werner H. Hofmann, Technische Universität Berlin (Germany) 